\title{
Twinning in dairy cattle and its effect on milk yield, lactation length, dry period length and calf performance
}

\author{
A. S. Mostafa* \\ Department of Hygiene, Management and Zoonoses, Faculty of Veterinary Medicine, Beni-Suef \\ University, Beni-Suef 62511, Egypt
}

\begin{abstract}
The twinning rate in a herd of Holstein dairy cattle and its effect on lactation and calf performance was investigated by using records of 5815 calving events. Data from twin calving Holstein cows in (TEC-DAP) farm in Al-Fayum Governorate between January 1997 and April 2008 were compared to those giving singles to study the differences in subsequent milk yield, previous and subsequent lactation and dry period length, as well as calf performance. The obtained average twinning rate was $1.4 \%$ during the period of the study. Cows giving twins had a significantly $(p<0.01)$ lower daily, peak and 305-d milk yields than those with singles. There was no significant difference $(p>0.05)$ in previous and subsequent lactation and dry period length between cows calving twins or singles. Calves born as twins were significantly $(p<0.005)$ lighter at birth and weaning time than single calves, whereas total birth weight and total weaning weight were significantly $(\mathbf{p}<\mathbf{0 . 0 0 5})$ increased for twins than singles. Daily body weight gain from birth to weaning was significantly lower $(p<0.005)$ for twin than single calves. Twinning in dairy cattle has a negative depressive effect on subsequent milk yield. Calf weight produced at weaning per cow calving can be increased in cows producing twins relative to cows producing singles. Alleviation of twinning constraints including dystocia, reduced calf survival and low reproductive performance requires improved management practices and early diagnosis of cows gestating twins in order to provide higher nutritive requirements in the last trimester of gestation and proper timing of drying off, and for higher assistance requirements at parturition. Thus, due to the increased disadvantages which did not offset the additional returns earned by calves, twinning in dairy cattle via selection or artificial induction appears not to be desirable.
\end{abstract}

The twinning rate in dairy cattle seems to have increased recently, and this may have important practical implications (Kinsel et al., 1998). The regulation of ovulation rate appears to be the primary mechanism for regulating litter size (Wiltbank et al., 2000). A number of factors were identified as possible regulators of twinning rates including age of dam (Jones and Rouse, 1920; Fricke and Wiltbank, 1999; Wiltbank et al., 2000), season (Cole and Rodolf, 1924) and genetics (Lush, 1925). Other factors have been found to be associated with twinning, including use of antibiotics or reproductive hormones, ovarian cysts, days open, and peak milk production (Pfau et al., 1948; Johansson et al., 1974; Nielen et al., 1989; Ryan and Boland, 1991; Lopez-Gatius et al., 1996; Kinsel et al., 1998; Wiltbank et al., 2000).Studies of the effects of twin births on milk production in the

\footnotetext{
* Corresponding author. Tel.: +20 0822322066; fax: +20822327982 .

E-mail address: asm@bsu.edu.eg (A. S. Mostafa).
}

subsequent lactation are contradictory. Cows with twins had greater milk production than cows with singletons (Auran, 1974; Syrstad, 1974; Wood, 1975; Kay, 1978; Wood, 1984; Eddy et al., 1991) while in others lower milk yields were recorded (Bar-Anan and Bowman, 1974; Suchanek, 1977; Syrstad, 1977; Chapin and Van Vleck, 1980). Effect of twinning on birth weight, weaning weight and growth of calves has been investigated in several studies (Bellows et al., 1971; Turman et al., 1971; Bellows et al., 1974; Johansson et al., 1974; Davis et al., 1989; Gregory et al., 1990, 1996; Echternkamp and Gregory, 2002; Bell and Roberts, 2007). The aim of this study included the determination of twinning rate in a Holstein dairy cattle herd and investigation of its effect on milk yield, lactation length, dry period length and calf performance.

\section{Materials and Methods}

Management. Holstein dairy cattle were housed and milked three times daily in a milking parlour system provided with a sheltered and fenced 
yards. Total mixed ration (TMR) according to (NRC 2001) was available all the day round based on corn silage, yellow corn, soya bean meal, cotton seed meal, hay, dicalcium phosphate in addition to mineral and vitamin premix. Estrus was detected by the use of electronic pedometer and cows that confirmed in estrus were artificially inseminated. Pregnancy diagnosis was done by rectal palpation at 35-48 days after insemination. Cows were dried off at an average of two months according to milk yield, conception time, and gestation length which control the length of this period. At the time of drying the teats were dipped in iodophor antiseptic solution and long acting antibiotic was infused intramammary. Pregnant cows were isolated in collective calving area at 7-10 days before expected calving date. After parturition live calves were left to be licked and dried by their mothers and the umbilical cord was cut, ligated and disinfected by iodophor solution. After that calves were separated from their mothers, transferred to calf hutch, identified by a metal ear tag and given colostrums by use of a nipple-bottle which was repeated every six hours and continued for four days. Calves were fed on whole milk at a rate of $10 \%$ of body weight by use of nipple-bottles. Calf starter, straw and water were available all the day to claves after one week of age till weaning. Claves were dehorned at an age of two months by electric dehorner. Weaning of calves was done at an average of 85 days.

Data collection. Data of 5815 calving events in (TEC-DAP) farm in Al-Fayum Governorate were extracted from the farm computer records in the period from January 1997 to April 2008 and used for statistical analysis. These data include cow identification, insemination date, calving date, milk yield (daily yield, peak yield and 305 day yield) subsequent to twin and single calvings, lactation length and dry period length prior and subsequent to twin and single calvings, number of calves born alive or dead (single or twin), calf birth weight, total calf birth weight per cow calving (calculated for those calves born alive), weaning weight, total calf weaning weight per cow calving (calculated as the number of live calves weaned at weaning time after subtracting of dead calves) and daily gain in body weight (weaning weight-birth weight in $\mathrm{kg} /$ weaning period in days).

Statistical analysis. Twinning rate was calculated as the number of twins born per cow calvings. For comparing the effect of twin and single calvings on milk yield, lactation length, dry period length, calf birth weight, total calf birth weight, calf weaning weight, total calf weaning weight and daily gain in body weight, data were analyzed by $t$-test using SPSS 13.0 according to (Norusis, 2004).

\section{Results and Discussion}

Twinning rate in Holstein dairy cows in the period from 1997 to 2007 is shown in Table1. The twinning rate in this period is ranged from 1.0 to $2.3 \%$ with an average of $1.4 \%$. The obtained average twinning rate in the present study is lower than the range (2.2 to $6.9 \%)$ reported in previous studies (Meadows and Lush, 1957; Erb and Morrison, 1959; Cady and Van Vleck, 1978; Nielen et al., 1989; Markusfeld, 1990; Eddy et al., 1991; Esslemont and Spincer, 1993; Peeler et al., 1994; Day et al., 1995; Kinsel et al., 1998; Bell and Roberts, 2007; Silva del Río et al., 2007; Al-Samarai, 2009), but within the range reported by Sreenan and Diskin (1989). This result suggests that the incidence of twinning is not a biologically fixed rate and that differences in herd management may allow some control of the incidence of twin birth. The difference in twinning rate may be related to multiple factors, including multiple ovulation rate, breed, parity, milk production, season and year of conception (Syrstad, 1974; Rutledge, 1975; Cady and Van Vleck, 1978; Ben-David, 1982; Bendixen et al., 1989; Nielen et al., 1989; Kinsel et al., 1998; Fricke, 2001). Wiltbank et al., (2000) proposed that high milk production increases steroid metabolism as a result of an increased blood flow to the digestive tract and the liver. The subsequent metabolism of the steroid oestradiol slows down the natural decline in follicle stimulating hormone, which means that follicles have more time to undergo physiological changes before they ovulate. Table 2 highlights the difference in milk yield of Holstein dairy cows following twin and single calvings expressed in daily yield, peak yield and 305-d yield. Milk yield subsequent to twin calving was lower $(\mathrm{p}<0.01)$ in terms of daily yield(23.27 kg), peak yield(41.92 kg) and 305-d yield(7097.79 $\mathrm{kg}$ ) than that following single birth with corresponding values of $(24.87 \mathrm{~kg} \mathrm{~kg})$,

$(46.31 \mathrm{~kg})$ and $(7585.35 \mathrm{~kg})$ respectively. The total loss in 305-d milk yield caused by twinning amounts to $487.5 \mathrm{~kg}$. So economic losses can result due to the negative effect of twin birth on

subsequent milk yield. These findings are in accordance with that obtained by (Bowman and Hendy, 1970; Hendy and Bowman, 1970; Bar- 
Table (1): Twinning rate in Holstein dairy cows in the period from 1997 to 2007.

\begin{tabular}{|c|c|c|c|c|c|c|c|c|c|c|c|c|}
\hline Year & 1997 & 1998 & 1999 & 2000 & 2001 & 2002 & 2003 & 2004 & 2005 & 2006 & 2007 & Average \\
\hline No. & $6 / 575$ & $9 / 582$ & $8 / 593$ & $9 / 605$ & $6 / 580$ & $7 / 600$ & $6 / 587$ & $7 / 561$ & $12 / 518$ & $4 / 283$ & $6 / 331$ & $80 / 5815$ \\
\hline $\begin{array}{l}\text { Twinning } \\
\text { rate }(\%)\end{array}$ & 1.0 & 1.5 & 1.3 & 1.5 & 1.0 & 1.2 & 1.0 & 1.2 & 2.3 & 1.4 & 1.8 & 1.4 \\
\hline
\end{tabular}

Table (2): Effect of twinning on subsequent milk yield in Holstein dairy cows.

\begin{tabular}{ccccccc}
\hline \multirow{2}{*}{ Milk yield (Kg) } & \multicolumn{3}{c}{ Twin } & \multicolumn{3}{c}{ Single } \\
\cline { 2 - 7 } & No. & Mean & SE & No. & Mean & SE \\
\hline Daily yield & 37 & 23.27 & 0.21 & 1230 & $24.87^{*}$ & 0.28 \\
Peak yield & 37 & 41.92 & 0.97 & 1230 & $46.31^{*}$ & 1.09 \\
305-d yield & 37 & 7097.79 & 129.35 & 1230 & $7585.35^{*}$ & 141.56 \\
\hline
\end{tabular}

* superscript within rows indicate significant difference at $\mathrm{p}<0.01$

Table (3): Effect of twinning on lactation and dry period length in Holstein dairy cows.

\begin{tabular}{lcccccc}
\hline $\begin{array}{c}\text { Parameters in relation to } \\
\text { calving (days) }\end{array}$ & \multicolumn{3}{c}{ Twin } & \multicolumn{3}{c}{ Single } \\
\cline { 2 - 7 } & No. & Mean & SE & No. & Mean & SE \\
\hline Previous lactation & 80 & 324.09 & 9.82 & 1230 & 338.43 & 4.52 \\
Subsequent lactation & 37 & 328.44 & 12.98 & 1230 & 339.13 & 6.38 \\
Previous dry period & 80 & 65.64 & 1.85 & 1230 & 62.74 & 1.39 \\
Subsequent dry period & 37 & 61.80 & 2.26 & 1230 & 62.47 & 1.22 \\
\hline
\end{tabular}

Table (4): Effect of twining on calf birth weight, weaning weight and body gain.

\begin{tabular}{lcccccc}
\hline \multirow{2}{*}{ Parameter (kg) } & \multicolumn{3}{c}{ Twin } & \multicolumn{3}{c}{ Single } \\
\cline { 2 - 7 } & No. & Mean & SE & No. & Mean & SE \\
\hline Calf birth weight & 134 & 27.64 & 1.56 & 1740 & $38.12^{*}$ & 0.62 \\
Total calf birth weight per cow calving & 134 & $46.29^{*}$ & 3.78 & 1740 & 36.84 & 1.01 \\
Calf weaning weight & 126 & 70.16 & 4.01 & 1625 & $87.44^{*}$ & 3.75 \\
Total calf weaning weight per cow calving & 126 & $110.50^{*}$ & 6.23 & 1625 & 78.93 & 2.12 \\
Daily body weight gain & 125 & 0.498 & 0.02 & 1625 & $0.584^{*}$ & 0.01 \\
\hline
\end{tabular}

* superscript within rows indicate significant difference at $\mathrm{p}<0.005$.

Anan and Bowman, 1974 ; Suchanek, 1977 ; Syrstad, 1977; Chapin and Van Vleck, 1980) but do not support results of (Auran, 1974; Syrstad , 1974; Wood, 1975; Kay, 1978; Wood, 1984; Eddy et al., 1991). In other studies reported by (Nielen et al., 1989; Bell and Roberts, 2007) there was no significant difference in 305-d milk yield between twin and single calvers. The low milk yield following twin birth may be related to the depressive effect of twin pregnancy on the concurrent lactation (Syrstad, 1977; Bareille et al., 2003). There is some thought that lobuloalveolar duct development in twin calvers is not as extensive as it may be in the single calvers due to shortened gestation period (Skjervold, 1977; Cady and VanVleck, 1978). Moreover, most of twin calving cows have a low body condition at parturition time which can 
negatively affect subsequent milk yield. The high energy demand of twin pregnancy at late gestation cannot be compensated due to short gestation length and consequently inadequate dry period for maintaining these demands (Bell and Roberts, 2007).

Means of lactation and dry period length prior and subsequent to twin and single calvings in Holstein dairy cows are given in Table 3. It can be recognized from these results that there is no significant difference $(\mathrm{p}>0.05)$ in length of previous lactation for twin (324.09 days) and single (338.43 days) producing cows. On the other hand, no significant difference was found for subsequent lactation in twin (328.44 days) and single (339.13 days) calvers. Although not significant, cows giving singletons had a longer previous and subsequent lactation than those giving twins by (14.3) and (10.6) days respectively. With regard to dry period length, there is no significant difference in length of previous (65.64 and 62.74 days) and subsequent (61.80 and 62.47 days) dry period in cows giving twins or singletons respectively. The lengths of lactation and dry period are mainly affected and controlled by gestation length, level of milk yield, reproductive success, management decisions and economic reasons. Twin pregnant cows should be dried off at least a week earlier than single pregnant cows due to shorter gestation length and high nutritive requirement during the last trimester, so that they have more than 60 days to get in suitable body condition for calving. Twin pregnant cows need a sufficient energy intake from their diet during the last 2 months of their lactation to ensure they have a body condition score as near to three as possible at the time of drying off, which can then be maintained to calving time. Similar results are also presented by (Bell and Roberts, 2007).

From Table 4 it can be recognized that calves born as twins were lighter $(27.64 \mathrm{~kg})$ at birth $(\mathrm{p}<0.005)$ than singles $(38.12 \mathrm{~kg})$ by 10.4 $\mathrm{kg}$ and this may be attributed to the nutrient supply from the dam directed into two fetuses rather than a single as well as the more roomy space inside the uterus for singles in comparison with twins. On the other hand, total calf birth weight per cow calving measured by those calves born alive was significantly increased $(\mathrm{p}<0.005)$ for twin calves $(46.29 \mathrm{~kg})$ as compared with singles $(36.84 \mathrm{~kg})$. Thus total birth weight of twin exceeded that of single claves by $25.6 \%$. Regarding weaning weight, twin calves had a lower $(p<0.005)$ weaning weight $(70.16 \mathrm{~kg})$ than singletons $(87.44 \mathrm{~kg})$ by $17.2 \mathrm{~kg}$ and this may be related to the difference in birth weight and body weight gain between twins and singles. Total weaning weight was increased $(p<0.005)$ for twin calves $(110.50 \mathrm{~kg})$ than for singles $(78.93$ $\mathrm{kg}$ ) by $31.5 \mathrm{~kg}(39.9 \%)$. The increased total birth weight and weaning weight in twin calves as compared with singles are mainly attributed to the increased number of calves born and weaned per cows giving twins than singles. With regard to daily body weight gain, single calves gained $86 \mathrm{~g}$ more $(\mathrm{p}<0.005)$ per day than twins from birth to weaning at about 85 days of age. The present results confirmed other findings obtained by (Bellows et al., 1971; Turman et al., 1971; Vincent and Mills, 1972; Bellows et al., 1974; Johansson, 1974; Kay et al., 1976; Anderson et al., 1978; Cady and VanVleck, 1978; Anderson et al., 1979; Anderson et al., 1982; Davis et al., 1989; Gregory et al., 1990, 1996; Echternkamp and Gregory, 2002; Bell and Roberts, 2007).

\section{Conclusion}

The reported twinning rate is lower than that obtained in other studies. Twinning in dairy cattle has a negative depressive effect on subsequent milk yield whereas lactation and dry period length are not affected. Calves born as singles are heavier at birth and weaning time than those born as twins. Calf weight produced at weaning per cow calving can be increased in cows producing twins relative to cows producing singles. However, the increased incidence of dystocia and low calf survival in twin calvings must be considered. Alleviation of twinning constraints including dystocia, reduced calf survival and low reproductive performance will require improved management practices and early diagnosis of cows gestating twins in order to provide for their higher nutritive requirements in the last trimester of gestation and proper timing of drying off, and for their higher assistance requirements at parturition. With palpation per rectum, pregnancy diagnosis between 30 and 60 days post breeding does not detect all twin pregnancies. Only those with ovulations from both ovaries and/or an amniotic sac in each horn can be detected by this way. So ultrasound holds promise for determining number of embryos or fetuses between day 30 and day 75 of gestation. Thus, due to the increased disadvantages which did not offset the additional returns earned by calves, twinning in dairy cattle via selection or artificial induction appears not to be desirable. 


\section{References}

Al-Samarai, F. R. (2009): Some factors influencing twinning rate in a herd of Holstein cattle in Iraq. Pakistan Vet. J., 29:1-4.(online article).

Anderson, G. B.; BonDurant, R. H. and Cupps, P. T. (1982): Induction of twins in different breeds of cattle. J. Anim. Sci., 54: 485-490.

Anderson, G.B.; Cupps, P. T. and Drost, M. (1979): Induction of twins in cattle with bilateral and unilateral embryo transfer. J. Anim. Sci., 49: 1037-1042.

Anderson, G. B.; Cupps, P. T.; Drost, M.; Horton, M. B. and Wright, R. W. (1978): Induction of twinning in beef heifers by bilateral embryo transfer. J. Anim. Sci., 46:449.

Auran, T. (1974): Multiple births in Norwegian cattle. Acta. Agr. Scan., 24: 207.

Bar-Anan, R. and Bowman, J. C. (1974): Twinning in Israel-Friesian dairy herds. Anim. Prod., 18:109.

Bareille, N.; Beaudeau, F.; Billon, S.; Robert, A. and Faverdin, P. (2003): Effects of health disorders on feed intake and milk production in dairy cows. Livest. Prod. Sci., 83: 53-62.

Bell, M. J. and Roberts, D. J. (2007): Effect of twinning on the feed intake, performance and health of dairy cows. Livest. Sci., 107: 274-281.

Bellows, R. A.; Short, R. E.; Anderson, D. C.; Knapp, B. W. and Pahnish, O. F. (1971): Cause and effect relationships associated with calving difficulty and calf birth weight. J. Anim. Sci., 33: 407-415.

Bellows, R. A.; Short, R. E.; Urick, J. J. and Pahnish, O. F. (1974): Effects of early weaning on postpartum reproduction of the dam and growth of calves born as multiples or singles. J. Anim. Sci., 39: 589-600.

Ben-David, B. (1982): Twin birth in cows. Refuah Vet., 39:67 (Abstract).

Bendixen, P. H.; Oltenacu, P. A. and Andersson, I. (1989): Case referent study of cystic ovaries as a risk indicator for twin calving in dairy cows. Theriogenology, 31: 1059-1066.

Bowman, J. C. and Hendy, C. R. C. (1970): The incidence, repeatability and effect on dam performance of twinning in British Friesian cattle. Anim. Prod. 12: 55.

Cady, R. A. and Van Vleck, L. D. (1978): Factors affecting twinning and effects of twinning in Holstein dairy cattle. J. Anim. Sci., 46: 950-956.

Chapin, C. A. and Van Vleck, L. D. (1980): Effects of twinning on lactation and days open in Holsteins. J. Dairy Sci., 63: 1881-1886.

Cole, L.J. and Rodolfo, A. (1924): Seasonal distribution of twin births in cattle. Rec. Proc. Am. Soc. Anim. Prod., Annual Mtg., 116-118.

Davis, M. E.; Harvey, W. R.; Bishop, M. D. and Gearheart, W. W. (1989): Use of embryo transfer to induce twinning in beef cattle: Embryo survival rate, gestation length, birth weight, and weaning weight of calves. J. Anim. Sci., 67: 301-310.

Day, J. D.; Leon, D. W. and Franti, C. E. (1995): Twin pregnancy diagnosis in Holstein cows: Discriminatory powers and accuracy of diagnosis by transrectal palpation and outcome of twin pregnancies. Can. Vet. J., 36: 93-97.

Echternkamp, S. E. and Gregory, K. E. (2002): Reproductive, growth, feedlot, and carcass traits of twin vs single births in cattle. J. Anim. Sci., 80 (E. Suppl. 2): E64E73.

Eddy, R. G.; Davies, O. and David, C. (1991): An economic assessment of twin births in British dairy herds. Vet. Rec., 129: 526-529.
Erb, R. E. and Morrison, R. A. (1959): Effects of twinning on reproductive efficiency in a Holstein-Friesian herd. J. Dairy Sci., 42: 512.

Esslemont, R. J. and Spincer, I. (1993): The incidence and costs of diseases in dairy herds. Page 33 in Daisy: The Dairy Information System Report. N0. 2. Univ. Reading, UK.

Fricke, P. M. (2001): Review: Twinning in dairy cattle. Prof. Anim. Sci., 17: 61-67.

Fricke, P.M. and Wiltbank, M.C. (1999): Effect of milk production on the incidence of double ovulation in dairy cows. Theriogenology. 52: 1133-1143.

Gregory, K. E.; Echternkamp, S. E. and Cundiff, L. V. (1996): Effects of twinning on dystocia, calf survival, calf growth, carcass traits and cow productivity. J. Anim. Sci., 74: 1223-1233.

Gregory, K. E.; Echternkamp, S. E.; Dickerson, G. E.; Cundiff, L. V.; Koch, R. M. and VanVleck, L. D. (1990): Twinning in cattle: III. Effects of twinning on dystocia, reproductive traits, calf survival, calf growth and cow productivity. J. Anim. Sci., 68: 3133-3144.

Hendy, C. R. C. and Bowman, J. C. (1970): Twinning in cattle. Anim. Breed, 38:22. (Abstract)

Johansson, I.; Lindhe, B. and Pirchner, F. (1974): Causes of variation in the frequency of monozygous and dizygous twinning in various breeds of cattle. Hereditas., 78: 201-234

Jones, S. V. H. and Rouse, J. E. (1920): Relation of age of dam to observed fecundity in domesticated animals. I. Multiple births in cattle and sheep. J. Dairy Sci., 3: 260290.

Kay, R. M. (1978): Changes in milk production, fertility and calf mortality associated with retained placentae or the birth of twins. Vet. Rec., 102: 477-479.

Kay, R. M.; Little, W. and Kitchenham, B. A. (1976): A comparison of the growth performance and blood composition of twin and singleton calves. Anim. Prod., 22:19.

Kinsel, M. L.; Marsh, W. E.; Ruegg, P. L. and Etherington, W. G. (1998): Risk factors for twinning in dairy cows. J. Dairy Sci., 81: 989-993.

Lopez-Gatius, F.; Labernia, J.; Santolaria, P.; LopezBejar, M. and Rutllant, J. (1996): Effect of reproductive disorders previous to conception on pregnancy attrition in dairy cows. Theriogenology, 46: 643-648.

Lush, R. H. (1925): Inheritance of twinning in Holstein cattle. J. Hered., 16: 273-280.

Markusfeld, O. (1990): Risk of recurrence of eight periparturient and reproductive traits of dairy cows. Prev. Vet. Med., 9: 279-286.

Meadows, C. E.; and Lush, J. L. (1957): Twinning in dairy cattle and its relation to production. J. Dairy Sci., 40: 1430

National Research Council (2001): Nutrient requirements of dairy cattle. $7^{\text {th }}$ Rev. ed. National Academy Press, Washington, DC.

Nielen, M.; Schukken, Y. H.; Scholl, D. T.; Wilbrink, H. J. and Brand, A. (1989): Twinning in dairy cattle: A study of risk factors and effects. Theriogenology, 32: 845-862.

Norusis, M. (2004): SPSS 13.0 Statistical Procedures Companion. Upper Saddle-River, N.J.: Prentice Hall, Inc.

Peeler, E. J.; Otte, M. J. and Esslemont, R. J. (1994): Interrelationships of periparturient diseases in dairy cows. Vet. Rec., 134: 129-132.

Pfau, K. O.; Bartlett, J. W. and Shuart, C. E. (1948): A 
study of multiple births in a Holstein-Friesian herd. J. Dairy Sci., 31: 241-254.

Rutledge, J. J. (1975): Twinning in cattle. J. Anim. Sci., 40: 803-815.

Ryan, D. P. and Boland, M. B. (1991): Frequency of twin births among Holstein-Friesian cows in a warm dry climate. Theriogenology, 36: 1-10.

Silva del Río, N.; Stewart, S.; Rapnicki, P.; Chang, Y.

M. and Fricke, P. M. (2007): An Observational Analysis of Twin Births, Calf Sex Ratio, and Calf Mortality in Holstein Dairy Cattle. J. Dairy Sci., 90: 1255-1264.

Skjervold, H. (1977): Tall Fra Fiøset. Buskap 09 Avdratt.29: 182. (Abstract).

Sreenan, J. M. and Diskin, M. G. (1989): Effect of a unilateral or bilateral twin embryo distribution on twinning and embryo survival rate in the cow. J. Reprod. Fertil., 87: 657-664.

Suchanek, B. (1977): Twinnings as related to milk performance and longevity of cows. Zivo Cisna Výroba., 22:651. (Abstr.)

Syrstad, O. (1974): Relationship between twin births and milk production in dairy cattle. Meldinger. Fra. Norg. Landbruksh, 53: 1-8.

Syrstad, O. (1977): Effects of twinning on milk production in dairy cattle. Livestock Prod. Sci., 4: 255-261.

Turman, E. J.; Laster, D. B.; Renbarger, R. E. and Stephens, D. L. (1971): Multiple births in beef cows treated with equine gonadotropin (PMS) and chorionic gonadotropin (HCG). J. Anim. Sci. 32: 962.

Vincent, C. K. and Mills, A. C. (1972): Gonadotropin levels for multiple births in beef cattle. J. Anim. Sci., 34: 77-81.

Wiltbank, M. C.; Fricke, P. M.; Sangsritavong, S.; Sartori, R. and Ginther, O. J. (2000): Mechanisms that prevent and produce double ovulations in dairy cattle. J. Dairy Sci., 83: 2998-3007.

Wood, P. D. P. (1975): A note on the effect of twin births on production in the subsequent lactation. Anim. Prod., 20: 421-424.

Wood, P. D. P. (1984): Some attributes of twin-bearing British Friesian and Canadian Holstein cows recorded in England and Wales. J. Anim. Res., 51: 365-370.

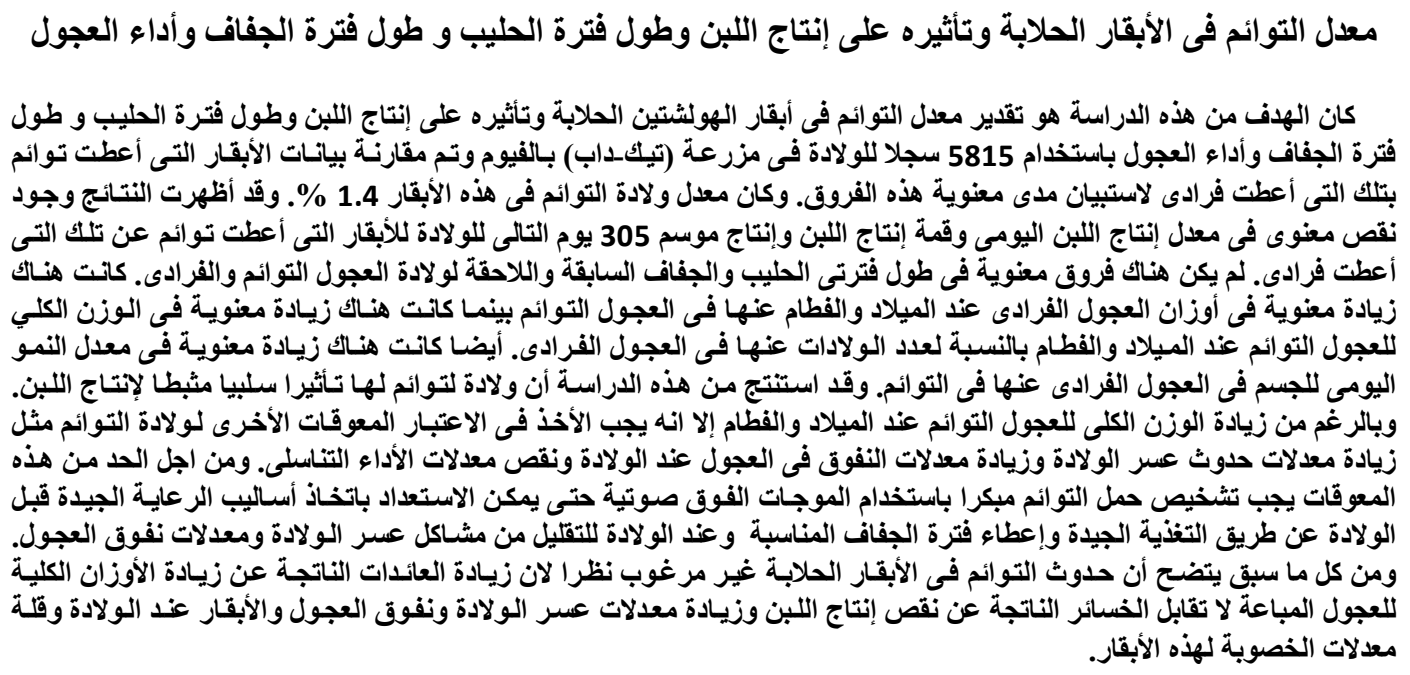

